\title{
STIMULATION GROWTH AND PRODUCTIVITY OF Cucurbita moschata UNDER RECLAIMED SALINE SOIL CONDITION BY USING SULPHUR SOIL APPLICATION AND ASCORBIC ACID FOLIAR SPRAY \\ Osman A. S. ${ }^{1}$ and Rewaa S. El-Shatoury ${ }^{2}$ \\ ${ }^{1}$ Department of Horticulture, Faculty of Agriculture, Fayoum University, Fayoum, Egypt \\ 2 Department of Horticulture, Faculty of Agriculture, Suez Canal University, Ismalia, Egypt
}

\begin{abstract}
The effects of soil application with sulphur (SAS) at a rate of $200 \mathrm{~kg} \mathrm{fed}^{-1}$ and/or foliar application with 0,1 or $2 \mathrm{mM}$ of ascorbic acid (FAA) on the growth, fruit yield and yield components, the concentrations of potassium (K), sodium (Na), sulphur (S) and ascorbic acid (AsA), and the ratio of $\mathrm{K} / \mathrm{Na}$ of pumpkin (Cucurbita moschata Duchesne) plants grown on a newly-reclaimed saline soil were investigated. Two field experiments (2012 and 2013) were performed on a newly-reclaimed saline soil using a design of completely randomized blocks with six treatments, each with four replicates. Results indicated that SAS and/or FAA increased growth traits (i.e., stem length, canopy dry weight plant ${ }^{-1}$, number of leaves plant ${ }^{-1}$, average leaf area and total leaf area plant ${ }^{-1}$ ), fruit yield and yield quality (i.e., fruit length and diameter, flesh thickness, TSS, average fruit weight and fruit yield fed ${ }^{-1}$ ), leaf concentrations of $N, P$, $\mathrm{K}, \mathrm{S}$ and $\mathrm{AsA}$, and $\mathrm{K} / \mathrm{Na}$ ratio. In contrast, leaf concentration of $\mathrm{Na}$ was reduced as a result of SAS and/or FAA. SAS and FAA, therefore, have the potential to be used as a soil and foliar applications, respectively for pumpkin to overcome the adverse effects of the newly-reclaimed saline soils.
\end{abstract}

Keywords: Pumpkin, Cucurbita moschata, sulphur, ascorbic acid, salinity, growth, yield.

\section{INTRODUCTION}

Pumpkin is widely cultivated on newly-reclaimed soils in the Middle Eastern countries, including Egypt. It is consumed in different local dishes and used for some food industries such as jams, purees and cakes. In Egypt, most newly-reclaimed soils are affected by salinity and have low fertility and a poor soil structure. The sustainability of crop production is primarily a function of various environmental stress factors, including salinity (Kumar et al., 2009), which is associated with the fertility status of the soil (Sogbedi et al., 2006). Soil fertility is adversely affected by salinity, which has emerged as one of the most serious factors limiting plant growth and productivity, and soil health (Turkan and Demiral, 2009). The loss in plant productivity due to salinity arises as a consequence of an imbalance in ion and nutrient concentrations and osmotic effects (Ashraf, 2009). These lead to the over-production of reactive oxygen species (ROS) compared with their levels in aerobic metabolic processes in chloroplasts, mitochondria, and peroxisomes under normal physiological conditions. The over-production of ROS causes oxidative damages to lipids, proteins and nucleic acids, and affects the properties of cell membranes (Ahmad et al., 2008). The ionic imbalance occurs in the cells due to the excessive accumulation of $\mathrm{Na}^{+}$and $\mathrm{Cl}^{-}$, and the 
reduction in the uptake of some mineral nutrients such as $\mathrm{K}^{+}, \mathrm{Ca}^{2+}$ and $\mathrm{Mn}^{2+}$ (Hasegawa et al., 2000; Tester and Davenport, 2003). Salt stress affects plant physiology, both at the whole plant and cellular levels, through osmotic and ionic stress. Salinity generates a 'physiological drought' or osmotic stress by affecting the plant water relations (Munns, 2002). Photosynthesis is one of the most severely affected processes under salinity stress (Sudhir and Murthy, 2004), which is mediated by decreased levels of chlorophyll and the inhibition of Rubisco (Soussi et al., 1998). All these and others altered processes leading to a poor plant growth and a subsequent loss in productivity. However, plants are well-equipped with antioxidant enzymes such as superoxide dismutase (SOD), catalase (CAT), and peroxidase (POX), and non-enzymatic anti-oxidants such as ascorbic acid, glutathione, or carotenoids, to counter any oxidative stress and to protect the plants from oxidative damage (Apel and Hirt, 2004).

Little information is available on the mineral nutrient status of plants and their tolerance to salinity. Among the mineral nutrients, sulphur (S) is increasingly being recognized as the fourth major essential nutrient element after nitrogen $(\mathrm{N})$, phosphorus $(\mathrm{P})$, and potassium $(\mathrm{K})$. Sulphur plays an important role not only in the growth and development of higher plants, but is also associated with increased stress tolerance in plants (Nazar et al., 2011; Osman and Rady, 2012, 2014). Deficiency of S negatively affects the chlorophyll, $\mathrm{N}$ contents of leaves and photosynthetic enzymes (Lunde et al., 2008), and consequently the reduction in yields and quality parameters of crops (Hawkesford, 2000; Osman and Rady, 2012, 2014). Adequate S nutrition improves photosynthesis and the growth of plants, and has regulatory interactions with $\mathrm{N}$ assimilation (Scherer, 2008). It is required for protein synthesis, $\mathrm{N}$ assimilation, and is a structural constituent of several coenzymes and prosthetic groups (Marschner, 1995). It is also incorporated into organic molecules in plants and is located in thiol $(-\mathrm{SH})$ groups in proteins (cysteine residues) and non-protein thiols (e.g., glutathione). The pool size of some thiol-containing compounds, especially reduced glutathione (GSH) which is sensitive to an oxidizing environment, represents a potential modulator of the stress response (Szalai et al., 2009; Osman and Rady, 2012, 2014). Glutathione has been shown to take part in the removal of excess ROS (Noctor and Foyer, 1998), controlling ROS levels (Rausch et al., 2007), and protecting plants from oxidative damage. In many agricultural areas, $\mathrm{S}$ is applied to ameliorate saline and alkaline soils. In Egyptian soils, which are characterized by a rise in $\mathrm{pH}, \mathrm{S}$ reduces soil $\mathrm{pH}$ values by the oxidation of $\mathrm{S}$ to sulphate through various species of soil microorganisms (EIEweddy et al., 2005; Osman and Rady, 2012, 2014). Decreasing soil pH improves the availability of microelements (e.g., Fe, Zn, Mn, and Cu; Hetter, 1985) and improves the chemical properties of alkaline soils as well as increasing yields and related characteristics (Kineber et al., 2004; Osman and Rady, 2012, 2014). On the other hand, some trials have been made to alleviate the disturbances in plant metabolism excreted by salinity stress. It has been suggested that some antioxidants, including ascorbic acid (AsA) may help to overcome some of these inhibitory effects. AsA is an important antioxidant defence in plant cells (Foyer and Halliwell, 1976) to protect them 
by scavenging the ROS. It also stimulates respiration activities, cell division and many enzymes activities (Innocenti et al., 1990). Latterly, there are widespread uses of natural and safety substances such as antioxidants, including AsA for enhancing growth and productivity of many crops. AsA has synergistic effect on plant growth, yield and chemical composition under favourable and unfavourable environmental conditions, i.e. salinity (Rady, 2006; Rady and Ekram Migawer, 2010; Osman, 2010; Osman and Rady, 2014).

Since salinity considers a potential threat to agricultural productivity, this work focused on generating ways to overcome the adverse effects of soil salinity stress on the growth, yield and yield components, the concentrations of $\mathrm{N}, \mathrm{P}, \mathrm{K}, \mathrm{Na}, \mathrm{S}$ and $\mathrm{AsA}$, and the ratio of $\mathrm{K} / \mathrm{Na}$ in pumpkin (Cucurbita moschata Duchesne) plants grown on a newly-reclaimed saline soil $(E C=$ $7.82-8.01 \mathrm{dS} \mathrm{m}^{-1}$ ) in two seasons (2012 and 2013) using $S$ and/or AsA as soil and foliar applications, respectively.

\section{MATERIALS AND METHODS}

Soil analysis, growth conditions and treatments

Two field experiments were conducted on pumpkin crop during the seasons of 2012 and 2013 in the Experimental Farm at Demo, Faculty of Agriculture, Fayoum University, Egypt. Prior to the initiation of each season, soil samples (up to $25 \mathrm{~cm}$ depth) from the experimental site were taken and analyzed according to the published procedures of Wilde et al. (1985) and the results are given in Tables (1 and 2).

Table 1: Some of the physical and chemical properties of the selected soil before planting in 2012 and 2013 seasons

\begin{tabular}{lcc}
\hline Property & $\mathbf{2 0 1 2}$ & $\mathbf{2 0 1 3}$ \\
\hline Physical: & & \\
Clay\% & 28.7 & 24.2 \\
Silt\% & 20.4 & 22 \\
Sand\% & 50.9 & 53.8 \\
Soil texture & sandy & sandy \\
Chemical: & & \\
Organic matter\% & 0.84 & 0.80 \\
$\mathrm{CaCO}_{3} \%$ & 6.66 & 6.82 \\
$\mathrm{Soluble}^{\circ}$ cations (meq $100^{-1} \mathrm{~g}$ soil): & & \\
$\mathrm{Ca}^{+2}$ & 12.63 & 14.52 \\
$\mathrm{Mg}^{+2}$ & 5.52 & 5.85 \\
$\mathrm{Na}^{+}$ & 43.54 & 45.16 \\
$\mathrm{~K}^{+}$ & 0.66 & 0.61 \\
$\mathrm{Soluble}$ anions (meq $100^{-1} \mathrm{~g}$ soil): & & \\
$\mathrm{CO}_{3}^{-}$ & - & - \\
$\mathrm{HCO}_{3}{ }^{-}$ & 3.17 & 3.13 \\
$\mathrm{Cl}^{-}$ & 33.23 & 35.61 \\
$\mathrm{SO}_{4}{ }^{2-}$ & 35.45 & 34.65 \\
$\mathrm{Macro}-$ and microelements (ppm): & & \\
$\mathrm{N}$ & 39.37 & 34.32 \\
$\mathrm{P}$ & 5.23 & 5.15 \\
$\mathrm{~K}$ & 90.16 & 85.41 \\
$\mathrm{Fe}$ & 4.17 & 4.03 \\
$\mathrm{Zn}$ & 0.63 & 0.60 \\
$\mathrm{Mn}$ & 2.02 & 2.03 \\
$\mathrm{Cu}$ & 0.47 & 0.44 \\
\hline
\end{tabular}


Table 2: Acidity and salinity of the experimental soil before soil application with sulphur (BSAS) and after 55 days from the soil application with sulphur (ASAS) in 2012 and 2013 seasons

\begin{tabular}{lccc}
\hline Sample & & $\mathbf{p H}$ & $\mathbf{E C}\left(\mathbf{d S ~ ~ ^ { - 1 } )}\right.$ \\
\hline \multirow{2}{*}{2012 season } & BSAS & 7.62 & 7.82 \\
\multirow{2}{*}{2013 season } & ASAS & 7.13 & 6.03 \\
& BSAS & 7.74 & 8.01 \\
& ASAS & 7.25 & 6.16 \\
\hline
\end{tabular}

Pumpkin seed (cv. Balady, Fayoum Governorate) was collected from fruits characterized by: skin color; orange, flesh color; orange, fruit size; large (> $4 \mathrm{~kg}$ ), fruit shape; pyriform-globular and shell; grooved. Then, seeds were washed with water, air-dried and kept at room temperature until the time of planting, seeds were sown on 11 March 2012 and 20 March 2013. The experimental design was completely randomized blocks with 6 treatments, each with 4 replicates. Each experimental unit measured $80 \mathrm{~m}^{2}$ and consisted of 5 rows; $8 \mathrm{~m}$ long and $2 \mathrm{~m}$ width, with row spacing averaged $50 \mathrm{~cm}$ apart. Each two adjacent experimental unites were separated by $1 \mathrm{~m}$ alley.

During soil preparation for planting, the elemental S (zero or $200 \mathrm{~kg} \mathrm{fed}^{-1}$ ) were broadcasted and incorporated, while pumpkin seedlings were foliar applied with AsA at 0,1 or $2 \mathrm{mM}$ to run off, two times; 25 and 40 days after sowing. Few drops of Tween-20 were added to the spraying solution as a wetting agent. In addition, all experimental areas were received a complete dose of farmyard manure $\left(15 \mathrm{~m}^{3} \mathrm{fed}^{-1} ; \mathrm{pH} 7.16\right.$ and 7.11 ; EC 3.23 and 3.12 dS $\mathrm{m}^{-1}$; organic matter $46.88 \%(\mathrm{w} / \mathrm{w})$ and $48.46 \%(\mathrm{w} / \mathrm{w}) ; \mathrm{C} / \mathrm{N}$ ratios 17.53 and 16.88; total N $1.72 \%(\mathrm{w} / \mathrm{w})$ and $1.47 \%(\mathrm{w} / \mathrm{w})$; total P $0.41 \%(\mathrm{w} / \mathrm{w})$ and $0.45 \%$ $(\mathrm{w} / \mathrm{w})$; and total $\mathrm{K} 0.69 \%(\mathrm{w} / \mathrm{w})$ and $0.72 \%(\mathrm{w} / \mathrm{w})$ in the 2012 and 2013 , respectively). The complete dose of calcium superphosphate $\left(15.5 \% \mathrm{P}_{2} \mathrm{O}_{5}\right)$ at the rate of $150 \mathrm{~kg} \mathrm{fed}^{-1}$ was applied. Mineral fertilizer rates of $200 \mathrm{~kg} \mathrm{~N}$ fed as ammonium nitrate $(33.5 \% \mathrm{~N})$ and $100 \mathrm{~kg} \mathrm{~K}_{2} \mathrm{O} \mathrm{fed}{ }^{-1}$ as potassium sulphate $\left(48 \% \mathrm{~K}_{2} \mathrm{O}\right)$ were also applied in two equal applications, i.e., at 30 and 60 days after sowing. Other agro-management practices were applied as recommended by the Egyptian Ministry of Agriculture for pumpkin production in newly-reclaimed soils.

\section{Measurements of growth traits}

Fifty-five days after sowing, five plants were randomly taken from the two outer rows of each experimental unit and cut off at ground level to measure the stem length, canopy dry weight plant $^{-1}$, number of leaves plant ${ }_{1}$, total leaf area plant ${ }^{-1}$ using a digital LI-3000 Portable area meter (LI-COR Lincoln, Nebraska, USA) and leaf area leaf ${ }^{-1}$ was calculated using the following formula:

$$
\begin{aligned}
& \text { Leaf area leaf }^{-1}=\frac{\text { Leaves area plant }^{-1}}{\text { Number of leaves plant }}{ }^{-1} \\
& \text { Measurements of fruit yield and yield quality }
\end{aligned}
$$

In each experimental unit, plants of the three middle rows were left to grow till the fruits approach the marketable stage. Then, fruits were picked from 20 plants to determine average fruit weight $(\mathrm{kg})$, fruit length $(\mathrm{cm})$ for the 
longitudinal axis starting from the peduncle junction to the blossom end, fruit diameter $(\mathrm{cm})$ at the maximum fruit diameter, flesh thickness of fruit $(\mathrm{cm})$, average of four measures, at the beginning of the fruit cavity, at the maximum fruit diameter, and at the blossom end, flesh samples were taken from four different parts of fruit and percent of total soluble solids (TSS\%) were measured using a hand heldle refractometer (HRN- 32, Kruss, Germany). The total yield of fruit fed ${ }^{-1}$ was calculated from all plants of the three middle rows.

\section{Nutrients and sodium determinations}

Leaf samples were collected from the fourth upper leaf of five randomly selected plants from each experimental unit after 60 days from planting. Samples were washed with tap water, rinsed three times with distilled water and some of them were dried at $70^{\circ} \mathrm{C}$ in a forced-air oven till constant weight. Some fresh leaf samples that randomly collected from all experimental units were subjected to the method of Helrich (1990) to determine their concentrations of endogenous ascorbic acid. The dried leaf samples were finely ground and sample weights of the fine powder $(0.2 \mathrm{~g})$ were digested using a mixture of sulphuric and perchloric acids to determine the following parameters: Nitrogen concentration was estimated using the Microkjeldahal apparatus as described in A.O.A.C. (1995). Phosphorus concentrations was colorimetrically estimated using the method of chloro-stannus molybdophosphoric blue color in sulphuric acid system according to the procedure of Jackson (1967). Potassium and sodium concentrations were determined using a Perkin-Elmer Flame photometer as outlined by Page et al. (1982). Sulphur concentration was measured by atomic absorption spectrophotometer (Analyst 300, Perkin-Elmer, Germany).

Statistical analysis

Data of the two seasons were subjected to the statistical analysis according to the design used (Snedecor and Cochran, 1980). The least significant difference test (LSD) test at $p \leq 0.05$ level was utilized to verify the significant difference between treatments.

\section{RESULTS}

\section{Vegetative Growth Traits}

Data in Table 3 show that stem length, canopy dry weight plant ${ }^{-1}$, number of leaves plant ${ }^{-1}$, average leaf area and total leaf area plant ${ }^{-1}$ increased in pumpkin plants, which foliar sprayed with ascorbic acid (AsA) at the 2 rates (1 and $2 \mathrm{mM}$ ) compared with plants, which not sprayed. Soil application with sulphur (S) further increased these growth traits. The best growth traits were obtained from the combined treatment of soil application with $S$ fertilizer and foliar application with $2 \mathrm{mM}$ AsA. The same trend was observed over both growing seasons. 
Table 3: Effect of soil application with sulphur (SAS; $\mathrm{kg} \mathrm{fed}^{-1}$ ) and foliar application with ascorbic acid (FAA; $\mathrm{mM}$ ) on vegetative growth traits [i.e., stem length (cm), canopy dry weight $\left(\mathrm{g} \mathrm{plant}^{-1}\right)$, number of leaves plant ${ }^{-1}$, leaf area $\left(\mathrm{dm}^{2}\right.$ leaf $\left.{ }^{-1}\right)$ and total leaf area $\left(\mathrm{dm}^{2}\right.$ plant $\left.\left.^{-1}\right)\right]$ of pumpkin plants grown in 2012 and 2013 seasons

\begin{tabular}{|c|c|c|c|c|c|c|}
\hline \multicolumn{2}{|c|}{ Treatment } & \multirow{2}{*}{ Stem length } & \multirow{2}{*}{ Canopy DW } & \multirow{2}{*}{ No. of leaves } & \multirow{2}{*}{$\begin{array}{c}\text { Leaf area } \\
\text { leaf }^{-1}\end{array}$} & \multirow{2}{*}{$\begin{array}{c}\text { Leaf area } \\
\text { plant }^{-1}\end{array}$} \\
\hline SAS & FAA & & & & & \\
\hline \multicolumn{7}{|c|}{2012 season } \\
\hline & 0 & $163 d$ & $75 d$ & $34 f$ & $2.14 d$ & $72.6 \mathrm{~d}$ \\
\hline \multirow[t]{3}{*}{0} & 1 & $175 \mathrm{~cd}$ & $86 \mathrm{~cd}$ & $37 e$ & $2.32 \mathrm{~cd}$ & $85.9 \mathrm{~cd}$ \\
\hline & 2 & $191 c$ & $95 c$ & $43 d$ & $2.42 \mathrm{c}$ & $104.1 \mathrm{c}$ \\
\hline & 0 & $231 b$ & $121 b$ & $51 \mathrm{c}$ & $2.72 b$ & $138.3 b$ \\
\hline \multirow[t]{3}{*}{200} & 1 & $255 a$ & $137 a$ & $56 \mathrm{~b}$ & $2.93 a b$ & $163.8 \mathrm{a}$ \\
\hline & 2 & $266 a$ & $\begin{array}{l}145 \mathrm{a} \\
\text { 2013sea }\end{array}$ & $61 a$ & $3.11 \mathrm{a}$ & $188.9 a$ \\
\hline & 0 & $156 d$ & $69 d$ & $33 e$ & $2.09 d$ & $69.7 d$ \\
\hline \multirow[t]{3}{*}{0} & 1 & $167 c d$ & $78 \mathrm{~cd}$ & $37 d$ & $2.19 \mathrm{~cd}$ & $80.6 \mathrm{~d}$ \\
\hline & 2 & $183 \mathrm{c}$ & $87 c$ & $44 c$ & $2.36 c$ & $103.2 \mathrm{c}$ \\
\hline & 0 & $222 \mathrm{~b}$ & $117 \mathrm{~b}$ & $49 \mathrm{~b}$ & $2.62 b$ & $128.0 \mathrm{~b}$ \\
\hline \multirow[t]{2}{*}{200} & 1 & $243 a$ & $131 a$ & $54 a$ & $2.84 a b$ & $153.1 \mathrm{a}$ \\
\hline & 2 & $254 a$ & $139 a$ & $57 a$ & $2.93 a$ & $167.2 \mathrm{a}$ \\
\hline
\end{tabular}

Fruit yield and yield quality

Data in Table 4 show that, (except TSS), the fruit length and diameter, flesh thickness, average fruit weight and fruit yield fed ${ }^{-1}$ were increased in pumpkin plants when sprayed with $A s A$ at the 2 rates ( 1 and $2 \mathrm{mM}$ ) compared with plants have no AsA application. Plants received AsA at the rate of $2 \mathrm{mM}$ gave higher average fruit weight and fruit yield fed ${ }^{-1}$ than plants received only $1 \mathrm{mM}$. Soil application with $S$ further increased fruit yield of pumpkin plants. The highest fruit yield was obtained when the combined treatment of soil application with $S$ fertilizer and foliar spray with $2 \mathrm{mM}$ AsA was applied. The same trends were observed in both seasons.

Table 4: Effect of soil application with sulphur (SAS; $\mathrm{kg} \mathrm{fed}^{-1}$ ) and foliar application with ascorbic acid (FAA; mM) on yield and fruit quality [i.e., fruit length and diameter $(\mathrm{cm})$, flesh thickness (cm), TSS (\%), average fruit weight $(\mathrm{kg})$ and fruit yield (ton fed )] of pumpkin plants grown in 2012 and 2013 seasons

\begin{tabular}{|c|c|c|c|c|c|c|c|}
\hline \multicolumn{2}{|c|}{ Treatment } & \multirow{2}{*}{$\begin{array}{l}\text { Fruit } \\
\text { length }\end{array}$} & \multirow{2}{*}{$\begin{array}{c}\text { Fruit } \\
\text { diameter }\end{array}$} & \multirow{2}{*}{$\begin{array}{l}\text { Flesh } \\
\text { thickness }\end{array}$} & \multirow{2}{*}{ TSS } & \multirow{2}{*}{$\begin{array}{l}\text { Average fruit } \\
\text { weight }\end{array}$} & \multirow{2}{*}{$\begin{array}{l}\text { Fruit yield } \\
\text { fed }^{-1}\end{array}$} \\
\hline SAS & FAA & & & & & & \\
\hline \multicolumn{8}{|c|}{2012 season } \\
\hline & 0 & $15.8 d$ & $9.5 d$ & $2.8 d$ & $5.98 a b$ & $2.86 \mathrm{e}$ & 13.3e \\
\hline \multirow[t]{3}{*}{0} & 1 & $17.0 \mathrm{~cd}$ & $10.6 \mathrm{~cd}$ & $3.1 d$ & $5.89 a b$ & $3.11 \mathrm{e}$ & $14.6 \mathrm{e}$ \\
\hline & 2 & $18.3 c$ & $11.4 c$ & $3.3 c$ & $5.81 b$ & $3.45 d$ & $16.4 d$ \\
\hline & 0 & $23.3 b$ & $15.6 b$ & $3.8 b$ & $6.07 a$ & $4.09 c$ & $19.6 c$ \\
\hline \multirow[t]{4}{*}{200} & 1 & 25.0ab & 16.3ab & $4.0 \mathrm{a}$ & $6.00 \mathrm{a}$ & $4.36 \mathrm{~b}$ & $21.1 b$ \\
\hline & 2 & $25.8 a$ & $17.0 \mathrm{a}$ & $4.2 a$ & 5.92ab & $4.66 a$ & $22.6 a$ \\
\hline & \multicolumn{7}{|c|}{2012 season } \\
\hline & 0 & $14.0 d$ & 8.3d & $2.4 d$ & $6.05 a b$ & $2.83 \mathrm{e}$ & $13.2 \mathrm{e}$ \\
\hline \multirow[t]{3}{*}{0} & 1 & $15.4 \mathrm{~cd}$ & $9.2 \mathrm{~cd}$ & $2.7 c$ & $6.00 \mathrm{ab}$ & $3.03 e$ & $14.2 \mathrm{e}$ \\
\hline & 2 & 16. $9 c$ & $9.7 \mathrm{c}$ & $2.9 c$ & $5.91 b$ & $3.36 d$ & $15.9 d$ \\
\hline & 0 & $22.8 b$ & $13.6 b$ & $3.4 b$ & $6.11 \mathrm{a}$ & $4.04 \mathrm{c}$ & $19.4 c$ \\
\hline \multirow[t]{2}{*}{200} & 1 & 24.0ab & 14.5ab & 3.7ab & $6.07 a b$ & $4.30 \mathrm{~b}$ & $20.9 b$ \\
\hline & 2 & 25.3a & 15.1a & $3.9 a$ & $6.02 \mathrm{ab}$ & $4.59 a$ & $22.4 \mathrm{a}$ \\
\hline
\end{tabular}


Leaf concentrations of $\mathrm{N}, \mathrm{P}, \mathrm{K}, \mathrm{S}, \mathrm{Na}$ and ascorbic acid(AsA)and $\mathrm{K} / \mathrm{Na}$ ratio

Data in Table 5 reveal that, except the reduction in the concentrations of $\mathrm{Na}$, the concentrations of $\mathrm{N}, \mathrm{P}, \mathrm{K} \mathrm{S}$ and $\mathrm{AsA}$, and the ratio of $\mathrm{K} / \mathrm{Na}$ were increased in pumpkin plants, which sprayed with 1 or $2 \mathrm{mM}$ AsA compared with those in plants have no AsA application. Plants applied with AsA at the rate of $2 \mathrm{mM}$ had higher $\mathrm{N}, \mathrm{P}, \mathrm{K}$ and AsA concentrations, and $\mathrm{K} / \mathrm{Na}$ ratio, and had no differences compared to plants sprayed with $1 \mathrm{mM}$. Further increased concentrations of $\mathrm{N}, \mathrm{P}, \mathrm{K}, \mathrm{S}$ and $\mathrm{AsA}$ and increased ratio of $\mathrm{K} / \mathrm{Na}$ were observed with soil application with $\mathrm{S}$. The concentration of $\mathrm{Na}$ showed the reverse trend to other measurements. The best results were obtained from the combined treatment of soil application with $S$ and foliar application with 2 mM AsA. Similar trends were observed in both growing seasons.

Table 5: Effect of soil application with sulphur (SAS; $\mathrm{kg} \mathrm{fed}^{-1}$ ) and foliar application with ascorbic acid (FAA; $\mathrm{mM}$ ) on leaf concentrations of nitrogen $(\mathrm{N})$, phosphorus $(\mathrm{P})$, potassium $(\mathrm{K})$, sodium ( $\mathrm{Na})$, sulphur (S) and ascorbic acid (AsA), and the ratio of $\mathrm{K} / \mathrm{Na}$ in pumpkin plants grown in 2012 and 2013 seasons

\begin{tabular}{|c|c|c|c|c|c|c|c|c|}
\hline \multicolumn{2}{|c|}{ Treatment } & $N(\%)$ & \multirow[t]{2}{*}{ P (\%) } & K (\%) & $\mathrm{Na}(\%)$ & $\begin{array}{l}\mathrm{K} / \mathrm{Na} \\
\text { ratio }\end{array}$ & $\mathbf{S}(\%)$ & AsA (\%) \\
\hline & & & & & 12 seaso & & & \\
\hline \multirow{4}{*}{0} & 0 & $1.68 \mathrm{~d}$ & $0.249 d$ & $2.68 d$ & $0.63 a$ & $4.25 f$ & $0.67 \mathrm{c}$ & $0.020 \mathrm{c}$ \\
\hline & 1 & $1.84 \mathrm{~d}$ & $0.269 d$ & $2.75 \mathrm{~cd}$ & $0.60 a b$ & $4.58 \mathrm{e}$ & $0.67 \mathrm{c}$ & $0.028 \mathrm{~b}$ \\
\hline & 2 & $2.09 c$ & $0.303 c$ & $2.86 \mathrm{c}$ & $0.58 \mathrm{~b}$ & $4.93 d$ & $0.69 \mathrm{c}$ & $0.040 \mathrm{a}$ \\
\hline & 0 & $2.26 \mathrm{bc}$ & $0.336 \mathrm{~b}$ & $2.95 b c$ & $0.53 \mathrm{c}$ & $5.57 \mathrm{c}$ & $0.77 \mathrm{~b}$ & $0.021 \mathrm{c}$ \\
\hline \multirow[t]{4}{*}{200} & 1 & $2.47 \mathrm{~b}$ & $0.354 \mathrm{~b}$ & $3.02 b$ & $0.50 \mathrm{~cd}$ & $6.04 \mathrm{~b}$ & $0.79 a b$ & $0.031 b$ \\
\hline & 2 & $2.73 a$ & $0.389 a$ & $3.22 a$ & $0.48 \mathrm{~d}$ & $6.71 a$ & $0.82 a$ & $0.042 a$ \\
\hline & & \multicolumn{7}{|c|}{2013 season } \\
\hline & 0 & $1.75 \mathrm{~d}$ & $0.267 d$ & $2.79 \mathrm{c}$ & $0.65 a$ & $4.29 d$ & $0.71 \mathrm{c}$ & $0.018 \mathrm{c}$ \\
\hline \multirow[t]{3}{*}{0} & 1 & $1.91 \mathrm{~d}$ & $0.286 \mathrm{~cd}$ & $2.86 \mathrm{c}$ & $0.63 a b$ & $4.54 d$ & $0.72 \mathrm{c}$ & $0.030 \mathrm{~b}$ \\
\hline & 2 & $2.19 \mathrm{c}$ & $0.318 \mathrm{c}$ & $2.96 \mathrm{bc}$ & $0.60 \mathrm{~b}$ & $4.93 \mathrm{c}$ & $0.72 \mathrm{c}$ & $0.039 a$ \\
\hline & 0 & $2.43 b$ & $0.361 b$ & $3.07 a b$ & $0.55 \mathrm{c}$ & $5.58 \mathrm{~b}$ & $0.78 b$ & $0.019 \mathrm{c}$ \\
\hline \multirow[t]{2}{*}{200} & 1 & $2.64 a b$ & $0.379 a b$ & $3.14 \mathrm{a}$ & $0.53 \mathrm{~cd}$ & $5.92 \mathrm{~b}$ & $0.81 \mathrm{~b}$ & $0.032 \mathrm{~b}$ \\
\hline & 2 & $2.87 a$ & $0.409 a$ & $3.26 \mathrm{a}$ & $0.50 \mathrm{~d}$ & $6.52 \mathrm{a}$ & $0.85 a$ & $0.041 \mathrm{a}$ \\
\hline
\end{tabular}

\section{DISCUSSION}

The enhanced results in this study may be attributed to the improvement in $\mathrm{K}, \mathrm{K} / \mathrm{Na}$ ratio, endogenous $\mathrm{S}$ and endogenous AsA (Table 5) due to the exogenous application of $S$ and AsA. Soil application of $S$ resulted in the reduction in $\mathrm{pH}$ and $\mathrm{EC}$ of the tested soil (Table 2), which improved the solubilization of nutrients in the tested soil therefore provided plants with more bio-available nutrients for uptake by plant roots (Osman and Rady, 2012, 2014). Khan et al. (2005) have reported that sufficient $S$ application improved photosynthesis and growth through regulating $\mathrm{N}$ assimilation. Higher $\mathrm{N}$ concentrations following $\mathrm{S}$ application may result in increased sulphate accumulation by plants which is responsible for increased 
photosynthesis and plant DW (Osman and Rady, 2012, 2014). Increased endogenous concentration of AsA leads to protect plant cells and, consequently, protect the photosynthetic apparatus by scavenging reactive oxygen species (Zhang and Schmidt, 2000). AsA considers a most powerful ROS scavenger because of its ability to donate electrons in a number of enzymatic and non-enzymatic reactions. It can provide protection to membranes by directly scavenge the $\mathrm{O}_{2}^{-}$and $\mathrm{OH}^{-}$and by regenerate atocopherol from tocopheroxyl radical. In chloroplast, AsA acts as a cofactor of violaxanthin de-epoxidase thus sustaining dissipation of excess excitation energy (Smirnoff, 2000). In addition to the importance of AsA in the ascorbate-glutathione cycle, it also plays an important role in preserving the activities of enzymes that contain prosthetic transition metal ions (Noctor and Foyer, 1998). The AsA redox system consists of L-ascorbic acid, monodehydroascorbate and dehydroascorbate. Both oxidized forms of AsA are relatively unstable in aqueous environments while dehydroascorbate can be chemically reduced by glutathione to ascorbate (Foyer and Halliwell, 1976), thus vigorous plant growth will be obtained under stress conditions. In this regard, Elade (1992) stated a positive action for antioxidants, including AsA, on growth and attributed this finding to their effects on counteracting drought, salinity and other abiotic stresses and protecting plant cells against free radicals that are responsible for plant senescence, as well as to their auxinic action. In addition, AsA might regulate cell wall expansion, division and elongation through its action on cell vacuolarization (Gonzalez-Reyes et al., 1994; Cordoba-Pedregosa et al., 1996), improve the nutritional status and absorbing phenolic compounds, which lead to protect the growing tissues from toxic effects of the oxidized phenols (Gupta et al., 1980) and/or enhance the biosynthesis of carbohydrates (Ahmed, 2001) and translocation of sugars (Farag, 1996), which could be explain our results.

The improvement occurred in yield might be attributed to the enhanced effect of $S$ on plant growth and activating the bio-chemical processes in plants, i.e., respiration, photosynthesis and chlorophyll content, which increased yield and yield components (Hegazi, 2004; Osman and Rady, 2012, 2014). On the other hand, data in the Table 5 show that the relative decrease in Na uptake by plants may be due to the positive plant response to the applied S, which combated the negative effects of salt stress in the root zone as well as reduced soil $\mathrm{pH}$ and EC. These results are in agreement with those obtained by Osman and Rady (2012 and 2014), who stated that the pronounced bacterial activity, due to the applied elemental $S$, is capable to produce some hormones, which induce the proliferation of roots and root hairs that increase nutrient absorbing surfaces, as well as produce organic acids, which solublize inorganic and organic forms of mineral elements, and consequently increase stems and leaves dry wieghts then the yield and yield components. Al-Qubaie (2002) stated that AsA as an antioxidant has an auxinic action, a synergistic effect on the biosynthesis of carbohydrates and controlling the incidence of most fungi on plants, which favours a vigorous state and reflects on yields. In addition, Osman (2010) and Osman and Rady (2014) reported an increase in yield bulbs of leek plant and fruits of squash, respectively as a result in the foliar application with ascorbic acid. Results 
regarding the beneficial effect of AsA on yield are coherent with those reported by Rady (2006) and El-Yazal (2007). S in combination with AsA reduced soil $\mathrm{pH}$ and $\mathrm{EC}$ (Table 2) and increased the availability of nutrients (Table 5), resulting in a positive effect on plant growth (Table 3), and also protected soil productivity against excess salt effects. These results indicated that the combined application of $S$ plus AsA was beneficial for newlyreclaimed soils to alleviate the adverse effects of salinity stress and to improve sustainable crop productivity. On the other hand, the relative decrease in Na uptake by plants may be due to the positive plant response to the applied S, which ameliorated the negative effect of salt stress in the root zone (Osman and Rady, 2012, 2014). Foyer et al. (1990) stated that, the antioxidant; AsA prevented enzyme inactivation and the generation of more dangerous radicals and allowed flexibility in the production of photosynthetic assimilatory power. Moreover, electron transfer to $\mathrm{O}_{2}$ prevented over reduction of the electron transported chain, which reduced the risk of harmful back reactions within the photosystem. In addition, Elade (1992) and Farag (1996) proved that most antioxidants were responsible for accelerating the biosynthesis of various pigments. Results of this study are supported by the results of Ahmed and Abd El-Hameed (2004) who reported that the effect of antioxidants on producing healthy plants leads to support the plants to have a greater ability for uptake of elements. Moreover, Gonzalez-Reyes et al. (1994) concluded that ascorbate free radical caused hyperpolarization of plasma membranes, and this energization could then facilitate transport processes across such membranes.

\section{CONCLUSIONS}

The soil and foliar applications of sulphur (S) and/or ascorbic acid (AsA), respectively have been shown to enhance plant stress-defence responses, to act indirectly by improving general plant performance under stress, and to increase endogenous concentrations of $S$ and AsA, leading to an increase in plant growth and crop yield. Thus, the application of $S$ and/or AsA may provide a novel strategy to reduce the adverse effects of salinity through increased the synthesis of endogenous antioxidant compounds, including AsA. The uptake and assimilation of $S$ (as sulphate) were assisted by AsA and assumed to be a crucial determinant for plant survival under a wide range of adverse environmental conditions since various antioxidants, particularly AsA and S-containing compounds are involved in plant responses to salinity stress. Increased endogenous $S$ and AsA concentrations, in addition to providing a potential efficient antioxidant enzyme system, resulted in greater protection from salinity stress. Therefore, the application of $S$ and/or AsA may act to ameliorate the severity of the effects of salinity stress on pumpkin plants grown in newly-reclaimed saline soils. 


\section{REFERENCES}

O. A. C., 1995. Official methods of analysis, $12^{\text {th }}$ Ed. Association of official analytical chemists. Washington, D. C.

Ahmad, P., Sarwat, M., Sharma, S., 2008. Reactive oxygen species. Antioxidants and signaling in plants. J. Plant Biol., 51, 167-173.

Ahmed, A. M., 2001. Studies for controlling malformation and improving yield and fruit quality of hindy bisinnara mangoes by using active dry years, ascorbic acid and sulphur. Minia J. of Agric Res. \& Develop., 21, 219 233.

Ahmed, F. F., Abd El-Hameed, H. M., 2004. Influence of some antioxidants on growth, vine nutritional status, yield and quality of berries in banaty grapevines. Assiut J. of Agric. Sci., 35, $131-140$.

Al-Qubaie, A. I., 2002. Response of Ficus nitida L. seedlings to the application of some antioxidants under soil salinity conditions. Minia J. of Agric. Res. \& Develop., 22, 235 - 254.

Apel, K., Hirt, H. 2004. Reactive oxygen species: metabolism, oxidative stress and signal transduction. Annual Review of Plant Biology, 55, 373-399.

Ashraf, M., 2009. Biotechnological approach of improving plant salt tolerance using antioxidants as markers. Biotechnology Advances, 27, 84-93.

Cordoba-Pedregosa, M. C., Gonzalez-Reyes, J. A., Sandillas, M. S., navas, P., Cordoba, F., 1996. Role of apoplastic and cell-wall peroxidases on the stimulation of root elongation by ascorbate. Plant Physiol., 112, $1119-1125$.

Elade, Y., 1992. The use of antioxidants to control gray mould (Botrytis cineria) and white mould (Sclerotinia sclerotiorum) in various crops. Plant Pathol., 141, 417 -426.

El-Eweddy, E. A., Beheiry G. Gh. S., Alaga, M. D., 2005. The effect of elemental sulphur and synthetic soil conditions on some chemical properties and plant production of calcareous soils. Egyptian Journal of Applied Science, 20, 734-747.

El-Yazal, M. A., 2007. Effect of some antioxidants on growth, yield and some chemical constituents of onion (Allium cepa L.). Fayoum J. Agric. Res. \& Dev., 21, 162-176.

Farag, K. M., 1996. Use of urea, phenylalanine, thiamine or their combinations to accelerate anthocyanins development and their effect on the storage life of Flame seedless grapes. First Egyptian Hungarian Hort. Conf., Kafr El-Sheikh, Egypt, 15 - 17 Sept.

Foyer, C. H., Halliwell, B., 1976. The presence of glutathione and glutathione reductase in chloroplasts: a proposed role in ascorbic acid metabolism. Planta 133, 21-25.

Foyer, C. H., Furbank, R. T., Harbinson, J., Horton, P., 1990. The mechanism contributing to photosynthetic control of electron transport by carbon assimilation in leaves. Photosynth. Res., 25, $83-100$. 
Gonzalez-Reyes, J. A., Alcain, F. J., Serrano, A. Cordoba, F., Navas, P, 1994. Relationship between apoplastic ascorbate regeneration and stimulation of root growth in Allium cepa L. Plant Sci., 100, $23-29$.

Gupta, P. K., Nadgir, A. L., Macarentias, A. F., Jagannathan, V., 1980. Tissue culture of forest trees: Clonal multiplication Tecoma grandis L. (treak) by tissue culture. Plant Sci. Letters, 17, $259-268$.

Jackson, M.L., 1967. Soil Chemical Analysis. Prentice-Hall of India Private Limited, New Delhi, pp. 144-197 and 326-338.

Hasegawa, P., Bressan, R. A., Zhu, J. K., Bohnert, H. J., 2000. Plant cellular and molecular responses to high salinity. Annu. Rev. Plant Physiol. Plant Mol. Biol., 51, 463-499.

Hawkesford, M. J., 2000. Plant responses to sulphur deficiency and the genetic manipulation of sulphate transporters to improve S-utilization efficiency. Journal of Experimental Botany, 51, 131-138.

Hegazi, I. M. A., 2004. Maximizing wheat production in sandy soil by using some natural soil amendments. Egypt. J. Appl. Sci., 19, 214-226.

Helrich, K., 1990. Official Methods of Analysis. Vitamin C (Ascorbic Acid). 15th Edition. Association of Official Analytical Chemists. Benjamin Franklin Station, Washington, DC, USA. 1058-1059.

Hetter, B., 1985. Utilization of sulphur for amendment on calcareous soil in Jordan. Proceedings of the 2nd Arab Regional Conference on Sulphur and its Usages. Ryiadh, Saudi Arabia. 1, 85-100.

Innocenti, M. A., Bitonti, M., Arrigoni, O., Liso, R., 1990. The size of quiescent center in roots of Allium cepa L. grown with ascorbic acid. New Phytol., $114,507-509$.

Khan, N. A., Mobin, M., Samiull, A. H., 2005. The influence of gibberellic acid and sulfur fertilization rate on growth and S-use efficiency of mustard (Brassica juncea). Plant and Soil, 270, 269-274.

Kineber, M. F. A., El-Masry, A. A., Gohar, M. N., 2004. Effect of sulphur application and nitrogen fertilization on yield and its quality for some flax varieties in alkaline soil. Annals of Agricultural Science, 49, 53-69.

Kumar, G., Purty, R. S., Sharma, M. P., Singla-Pareek, S. L., Pareek, A., 2009. Physiological responses among Brassica species under salinity stress show strong correlation with transcript abundance for SOS pathway-related genes. Journal of Plant Physiology, 166, 507-520.

Lunde, C., Zy gadko, A., Simonsen, H. T., Nielsen, P. L., Blennow, A., Haldrup, A., 2008. Sulphur starvation in rice: the effect on photosynthesis, carbohydrate metabolism, and oxidative stress protective pathways. Physiologia Plantarum, 134, 508-521.

Marschner, H., 1995. Mineral Nutrition of Higher Plants. $2^{\text {nd }}$ Edition. Academic Press, New York, NY, USA., 559-579

Munns, R., 2002. Comparative physiology of salt and water stress. Plant Cell and Environment, 25, 239-250.

Nazar, R., lqbal, N., Masood, A., Syeed, S., Khan, N. A., 2011. Understanding the significance of sulfur in improving salinity tolerance in plants. Environmental and Experimental Botany, 70, 80-87. 
Noctor, G., Foyer, C.H., 1998. Ascorbate and glutathione: keeping active oxygen under control. Ann. Rev. Plant Physiol. Plant Mol. Biol. 49, 249-279.

Osman A. Sh., Rady, M. M., 2012. Ameliorative effects of sulphur and humic acid on the growth, anti-oxidant levels, and yields of pea (Pisum sativum L.) plants grown in reclaimed saline soil. J. Hort. Sci. \& Bio. 87, 626-632.

Osman A. Sh., Rady, M. M., 2014. Exogenously-applied sulphur and ascorbic acid positively altered their endogenous concentrations, and increased growth and yield in Cucurbita pepo L. plants grown on a newlyreclaimed saline soil. J. Biotechnol. Sci., 2(1), 1-8.

Osman, A. Sh., 2010. Efficiency of growth and productivity of leek plants as affected by organic manure and ascorbic acid under saline reclaimed soil conditions. Egypt. J. Hort., 37, $65-83$.

Page, A. I., Miller, R. H., Keeney, D. R., 1982. Methods of Soil Analysis. Part II. Chemical and Microbiological Methods. $2^{\text {nd }}$ ed. Amer. Soc. Agron., Madison, Wisconsin, USA.

Rady, M. M., 2006. Efficiency of growth and productivity of sunflower plants as affected by ascorbic acid under saline reclaimed soil conditions. The Second Conference on farm Integrated Pest Management, 16 - 18 Jan., pp. $186-200$.

Rady, M. M., Ekram, Migawer, A., 2010. Possibility of improving growth, physiological behavior and yield of canola plants cultivated in saline reclained soils with application of humic and ascorbic acids. Minufiya J. Agric. Res., 35, 863-883.

Rausch, T., Gromes, R., Liedschull, V., Muller, I., Bogs, J., Galovic, V., Wachter, A., 2007. Novel insight into the regulation of GSH biosynthesis in higher plants. Plant Biology, 9, 565-572.

Scherer, H. W., 2008. Impact of sulphur on $\mathrm{N}_{2}$ fixation of legumes. In: Sulphur Assimilation and Abiotic Stresses in Plants (Khan, N. A., Singh, S. and Umar, S. Eds.). Springer-Verlag, New York, pp. 43-54.

Smirnoff, N., 2000. Ascorbic acid: metabolism and functions of a multifaceted molecule. Curr. Opin. Plant Biol. 3, 229-235.

Snedecor, G.W., Cochran, W.G., 1980. Statistical Methods. $7^{\text {th }}$ ed., lowa State Univ. Press, Ames, lowa, USA.

Sogbedi, J. M., Van Es, H. M., Ageko, K. L., 2006. Cover cropping and nutrient management strategies for maize production in western Africa. Agronomy Journal, 98, 883-889.

Soussi, M., Ocand, A., Lluch, C., 1998. Effect of salt stress on growth, photosynthesis and nitrogen fixation in chickpea (Cicer arietinum L.). Journal of Experimental Botany, 49, 1329-1337.

Sudhir, P., Murthy, S. D. S., 2004. Effect of salt stress on basic process of photosynthesis. Photosynthetica, 42, 481-486.

Szalai, G., Kellos, T., Galiba, G., Kocsy, G., 2009. Glutathione as an antioxidant and regulatory molecule in plants under abiotic stress conditions. Journal of Plant Growth Regulation, 28, 66-80.

Tester, M., Davenport, R., 2003. Na tolerance and Na transport in higher plants. Annals of Botany, 91, 503-527. 
Turkan, I., Demiral, T., 2009. Recent developments in understanding salinity tolerance. Environmental and Experimental Botany, 1 (Special Issue): 2-9.

Wilde, S. A., Corey, R. B., Lyer, J. G., Voigt, G. K., 1985. Soil and Plant Analysis for Tree culture. Oxford and IBM Publishers. New Delhi. India. $3^{\text {rd }}$ ed. pp. 93-106.

Zhang, X., Schmidt, R. E., 2000. Hormone-E containing products impact on antioxidant status of tall fescue and creeping bent grass subjected to drought. Crop Sci., 40, $1344-1349$.

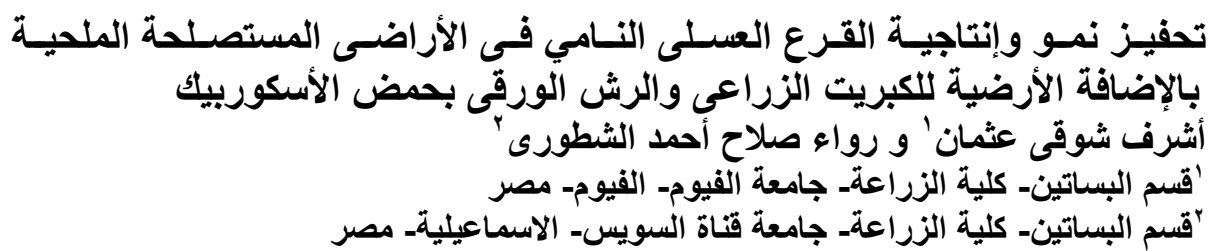

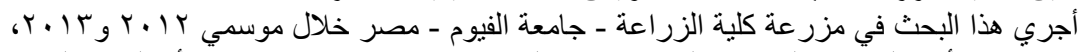

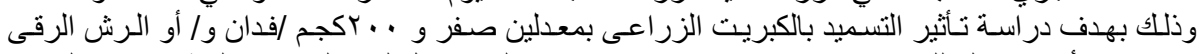

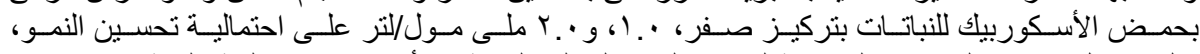

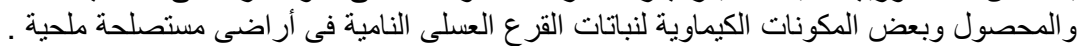

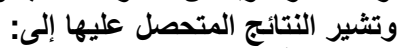

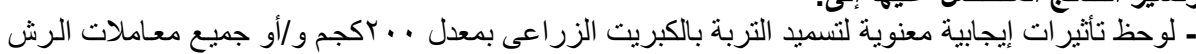

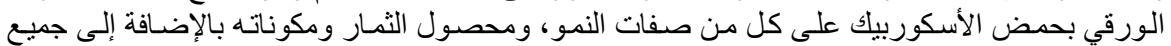

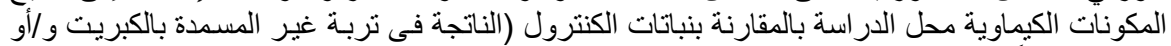

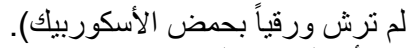

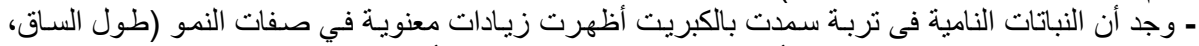

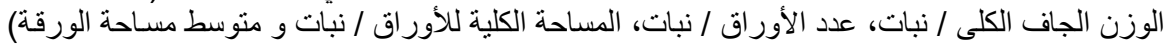

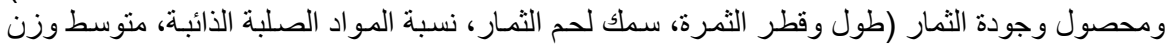

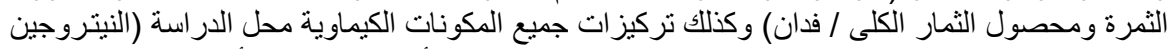

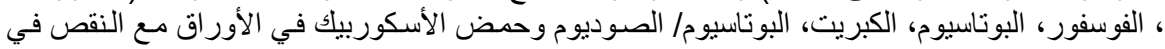

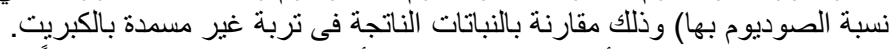

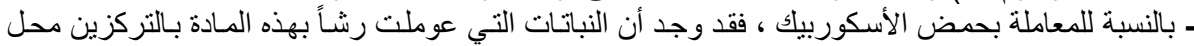

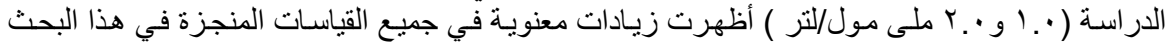

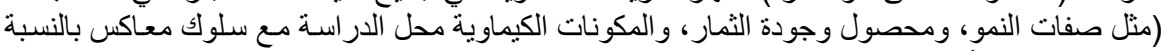

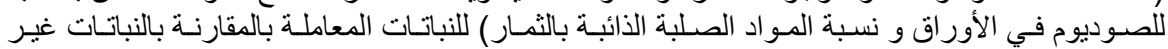

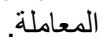

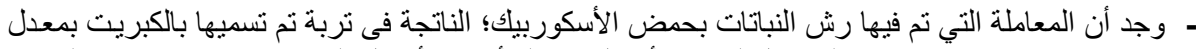

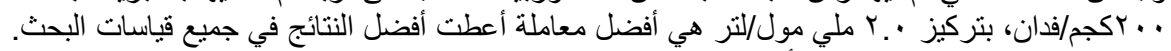

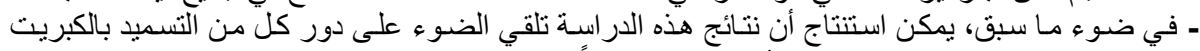

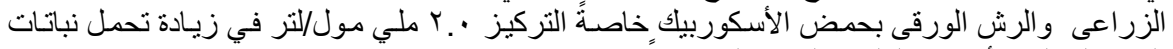

القرع العسلى الأرضى الملحية المستصلحة حديثًا. 